\title{
A NEW LOOK AT GLOBALIZATION: TAKING ACCOUNT OF THE DARK SIDE
}

\section{Murray Weidenbaum (USA)}

Listening to high decibel debates on globalization it is tempting to describe the process as ships passing in the night. Unfortunately, the situation is not that benign. Often these ships crash into each other. It is dismaying to observe the current round of high decibel debates. Participants on each side know they are right and are determined to convince everyone else of the errors of their ways. Worse yet, positions are hardening on both sides. Few even now listen to other views of globalization.

Let us sidestep the semantic issue of defining precisely the very word "globalization" because globalization is one of the great vacuum words of our time. It sucks up any meaning anyone wishes to ascribe to it. This article focuses on the array of impacts that arise from the increasing tendency for national borders to be crossed by people, goods, services, information, and ideas.

There is truth, exaggeration, and error on all sides of the debate on globalization. Very few look at both the bright side and the dark side. Most economists and business leader's focus on the benefits of globalization. ${ }^{1}$ their litany is familiar. A greater flow of international trade and investment stimulates economic growth. That rising output requires more employment and income payments and thus generates a higher living standard for consumers. Rising living standards in turn increase the willingness of the society to devote resources to the environment and other important social goals.

Global competition also keeps domestic businesses on their toes, forcing them to innovate and improve product quality and industrial productivity. After all, if competition is good, spreading it out internationally must be even better.

More fundamentally, rapidly developing economies generate a new middle class, the bulwark of support for personal liberty as well as economic freedom.

Finally, we are told that economic isolationism does not work. The most striking case was sixteenth century China, where one misguided emperor abruptly cut off trade and commercial intercourse with other nations. China had been the wealthiest, most technologically advanced, and the most powerful nation on the

${ }^{I}$ For a representative sample of the debates on globalization, see U.S. Trade Deficit Review Commission, The Trade Deficit (Washington, D.C.: U.S. Government Printing Office, 2000) and accompanying CD-ROM 
face of the globe. Yet it promptly went into a decline from which it has yet to fully emerge.

The real shortcoming of this line of thinking is not that the facts or analysis are wrong - but that the entire approach is an inadequate response to the critics.

The other voices in the globalization debate emphasize the dark side. Workers feel threatened by unfair competition from low-cost sweatshops overseas. Citizens generally worry about the conditions in those foreign sweatshops, especially for children. People who care about the environment see the pollution caused by the long distance movement of goods as well as the shift of production to overseas locations with low or no formal environmental standards. All of us witness global financial crises and widespread recession and, far worse, mass starvation amidst the collapse of whole societies in Africa.

Meanwhile, concerns abound about the supposed growing inequality of income around the world. Apparently, the poor are getting poorer while the rich are getting richer. Globalization may be good for the compilers of economic statistics. But, according to this viewpoint, it is the antithesis of justice and fairness. At the same time, government officials fear the loss of sovereignty and individuals see an erosion of liberty, while we all face the rising power of international crime syndicates, spreading epidemics, and most dramatically the unprecedented and audacious attacks by global terrorist groups.

Well, which is it? Is globalization the bright sun or the dark side of the moon? Before presenting a considered response, it is useful to note that economic historians tell us that, measured by trade and investment flows, the world economy may have been more integrated in the nineteenth century than it is today. Moreover, before passports were generally required for crossing borders, people were far freer to travel and to migrate than is now the case. ${ }^{2}$

The extent of economic interdependence across national boundaries-globalization - did not decline in the early $20^{\text {th }}$ century because of mass protests or a bad press. The precipitating factors were far more fundamental - World War I, the worldwide depression of the 1930s, and the subsequent separation of the major nations into democratic and totalitarian camps that culminated in World War II. That long period was a time of rising isolationism, both political and economic.

It is very possible that the world is approaching a somewhat similar turning point. The increasingly negative public reaction to the rapid and pervasive

${ }^{2}$ Jeffrey Williamson, Globalization and Inequality, NBER Working Paper No. 5491 (Cambridge, Massachusetts: National Bureau of Economic Research, 1996) 
changes generated by globalization is beginning to overtake the positive aspects - at least in terms of perception. The instinctive response by economists is to correct the substantial amount of misinformation that has fueled the growing backlash to opening markets and to expanding the reach of competitive forces.

Unfortunately, the education and information approach does not help with the newest negative force, the rise of international terrorist networks. The sad fact is that the combination of their activities and our responses almost invariably is making international trade more difficult and costly and international investment more hazardous and financially more risky. To sum up the most recent trends, the costs of globalization are rising while the benefits are declining. ${ }^{3}$

It is not clear how those seriously concerned with world commerce should proceed under these circumstances. Obviously, the terrorists are not going to be helpful. It is their diabolical use of the modern technology that has been pacing the rise of globalization which has enabled them to be so effective in the devastation that they generate. Only an economist would describe their efforts as very cost-effective, but they are.

So let us turn to the two more conventional sides of the globalization debate -those who favor freer markets and those who have other peaceful priorities. However, even here the degree of trust and open-mindedness necessary for the educational approach to succeed is lacking. That important task must be left to other occasions. Nor is it useful to ridicule the vague "reforms" supported by many of the protesters. I merely note that advocating the elimination of the evils of capitalism, however desirable, is not a practical program for improvement.

It is sad to note that, in each of the camps in the globalization debate, there are people who are not disposed to compromise in any significant degree. To many that would be "selling out". Fortunately, in each camp there are others who are willing at least to listen to some alternatives. Therefore, this article undertakes a modest task: to attempt to identify, amidst the heated controversies on globalization, some common ground on which people of good will on both sides of the chasm might possibly agree. The proposals presented below are meant to be constructive, albeit modest, responses to the critics of globalization. The focus is on some useful but unromantic policy changes, what can be called the "nuts and bolts" of problem solving.

${ }^{3}$ See Murray Weidenbaum, "Economic Warriors against Terrorism", the Washington Quarterly, Vol. 25, No. 1, winter 2002, pp. 43-52 


\section{Reform the World Trade Organization}

Many of the criticisms of the World Trade Organization are on target and they deserve a positive response. ${ }^{4}$ The WTO has become too closed and too bureaucratic. But there is no value in trying to shut it down. Its fundamental notion of advancing the rule of law on an international front is appealing.

Nevertheless, it does not diminish the adherence to free and open trade to state that the WTO has become too closed and too rigid in its operations. For starters, the general sessions of trade negotiations should be open to the public, like the Congress is. So should the hearings at which the various interest groups present their views. Yet like the legislative committees, the members should be expected to go into closed executive sessions when they begin to do the actual negotiations and drafting of trade agreements. That is a common sense distinction which experience teaches is practical and workable.

Similarly, the critical dispute settlement process of the WTO should be opened up. The process should be expanded to include the submission of amicus briefs by interested public and private groups. Even the Supreme Court allows for such submissions by outsiders, so-called "friends of the court." Also the hearings of the dispute panels should be open to government and private observers, as courtroom proceedings typically are. This does not require that the panel deliberations be public events.

\section{Help the People Hurt by Globalization}

Virtually any significant economic change generates winners and losers. It does not satisfy the people hurt by globalization - or even those who think they are - to tell them that far more people benefit from international trade and investment. Although that response is accurate, it is so cavalier that it is bound to infuriate those concerned with the dark side of globalization.

A two-prong approach is required. In the advanced industrialized nations, more effective methods need to be developed to help the people who lose their jobs due to imports or the movement of factories to overseas locations. Simultaneously, we must grapple with the issue of the labor and environmental standards that are followed in poor (and thus usually low cost) countries by the companies that provide products for export to developed nations. Many of these factories are either owned by companies in the developed world or sell the bulk of their output to those western companies.

${ }^{4}$ Bruce Stokes and Pat Choate, Democratizing U.S. Trade Policy (New York: Council on Foreign Relations, 2001) 
In the developed nations, the most effective adjustment policy to help those who lose their jobs due to globalization - or for other reasons, notably technological advance - is to achieve a growing economy that generates a goodly supply of new jobs. In the absence of a strong economy, no adjustment policy will work well. Nevertheless, some additional constructive actions can be taken.

Often laid-off workers need just a modest bit of help, but they need it quickly. These are the people who went straight from school to work and never had to conduct a serious job hunt. For them, the most effective assistance is modest but essential: show them how to locate a new job, how to prepare for a job interview, and how to fill out a job application. ${ }^{5}$

Many other unemployed people, however, find that their job skills are obsolete or that much of their knowledge is only useful to their previous employer. They may be long on what can be called institutional information, but extremely short on the math and language capabilities required for many new and well paying jobs. These people could benefit from some pertinent education and training. Such "trade adjustment" programs have existed in the United States for four decades, but their track record is not very inspiring.

Those public sector adjustment assistance programs need to be adjusted. They should be made more users friendly. "One stop" registration should replace the current uncoordinated array of assistance. It is disheartening for a newly unemployed worker to feel like a Ping-Pong ball being tossed from bureau to bureau, rarely encountering a government official who seems to have any real interest in his or her situation.

There is a type of educational and training institution that can be geared to serving unemployed blue collar and white-collar workers. It is the network of community and junior colleges that attract a very different group of people than do the more prestigious senior colleges and universities.

Older workers present an especially difficult challenge. They have limited motivation to undertake training programs that, at best, will prepare them for positions that pay much less than their customary wages - and in a labor market where they will compete against youngsters half their age.

Some innovations are needed. One example of fresh thinking is the idea of providing "wage insurance" to pay a major portion of the difference in earnings between the new job and the previous position. The idea is to give the older workers the incentive to get back to work quickly before their skills become

${ }^{5}$ Paul Decker and Walter Carson, "International Trade and Worker Displacement", Industrial and Labor Relations Review, Vol. 48, July 1995, pp. 758-774. 
rusty. To the extent that such older workers demonstrate to their new employers their greater worth in terms of seasoned judgment and good work habits, they may find the wage gap between the old and new jobs narrowing - and thus minimizing the need to draw on the wage insurance plan. ${ }^{6}$

An even more contentious area is the issue of establishing labor and environmental standards for overseas locations that make products for export to the developed nations. There are several contending groups involved, each of which has its own set of goals and objectives.

The labor unions in the industrialized countries resent the competition from workers in countries with lower costs of production and hence lower working standards. Certainly compared with pay and factory conditions in the United States, it is easy and sometimes accurate to label these places as "sweatshops."

As would be expected, employers, both at home and abroad, have a somewhat different attitude on the matter. They view using the low cost production sites overseas as necessary to meet competition. Many U.S. firms report that the factories they own or buy from in developing countries usually pay their workers substantially above locally prevailing wages. They also claim to maintain above average working conditions.

There is a third force in this debate, which really complicates the issue. It consists of the governments of the developing countries, such as India and Brazil. They openly resent what they describe as the newly-formed concern on the part of Westerners with the working conditions in their countries. They see that interest as a poorly disguised form of protectionism designed to keep their products out of the markets of the advanced economies - and also thus prevent their businesses and workers from entering the world economy. In the words of Egypt's trade minister, Yourself Boutros-Ghali: "Why, all of a sudden, when Third World labor has proved to be competitive, do industrial countries start feeling concerned about our workers?"7

A somewhat similar lineup of interest groups occurs in the case of environmental standards in developing countries. On the international trade front, unions and environmental groups tend to join forces. On domestic issues, however, they often go their separate ways, especially when the question seems to involve jobs versus the environment. ${ }^{8}$

${ }^{6}$ Gary Burtless, Robert Z. Lawrence, Robert E. Litan, and Robert J. Shapiro, Glob phobia (Washington, D.C.:Brookings Institution, 1998), pp. 143-145

${ }^{7}$ Quoted in Daniel E. Sanger, "A Grand Trade Bargain", Foreign Affairs, January/ February 2001, pp. 66-67

${ }^{8}$ See I.M. Deshler and Peter J. Baling, The New Politics of American Trade (Washington, D.C.: International Economics, 1999). 
In terms of action on globalization matters, most unions and many environmental organizations insist on directly linking labor and environmental standards with any new international trade agreement. Products produced in violation of the standards would be barred from entering other nations. Business interests strongly oppose that approach, as do most governments in developing countries. The result is a standoff preventing a new round of trade liberalization. The next two suggestions are examples of constructive alternatives.

\section{Strengthen the International Labor Organization}

One promising possibility is strengthening the International Labor Organization (ILO), the only international agency in which labor is fully represented. Yet unions are reluctant to use the ILO to enforce international labor standards - and for good reason. When it comes to ensuring compliance with the enlightened standards it adopts, the ILO has been a paper tiger. Worse yet, of the four "core" labor standards it has promulgated, the U.S. Congress has only gotten around to endorse two. Ironically, compared to our domestic labor laws and regulations, these four standards are far more moderate and limited. ${ }^{9}$

The "core" standards cover the right to form unions, ridding the workplace of discrimination in employment, and eliminating child and forced labor. The U.S. Congress should quickly endorse all four of the ILO standards. To follow up, the United States should take the lead in urging the other industrialized nations to join in providing adequate resources and support to the ILO.

Increases are justified for the funds for such enlightened ILO activities as the special program which provides financial assistance to poor families whose children are taken off factory employment. The idea is to enable those youngsters to stay in school. In many cases, the families cannot afford to pay for such education on their own - or even to forego the money the children had been earning.

In contrast, the current debate on using the WTO and trade sanctions to enforce labor and environmental standards is sterile and a dead end. The combined opposition of domestic business and the governments of developing nations virtually guarantee a continuing policy deadlock, with no serious action being taken.

\section{Give People a Voice via the Internet}

There is a way of promoting adherence to the ILO labor standards without

${ }^{9}$ Kimberly Ann Elliot, “Getting Beyond No..." in Jeffrey Schott, the WTO after Seattle, (Washington, D.C.: Institute for International Economics, 2001), pp. 187-204 
resorting to trade sanctions or other forms of compulsion. The ILO should post on the Internet the names of the countries that are not complying with the core labor standards. Such a "seal of disapproval" should be widely publicized, encouraging consumers around the world not to purchase goods made in those nations.

Is this a form of boycott? Well, yes and no. In this approach, governments would not use force to keep out the products from the offending countries. Rather each individual consumer would have the ability to back up concerns with personal action - with that action being based on knowledge rather than pressure.

This alternative approach does not provide the entertainment of puppetparading protestors. However, it may be more effective in the long run. To be successful a conscientious citizenry is required, one that takes the pains to inform itself and then acts voluntarily on an individual basis. Given the widespread access to the Internet, such a consumer effort could be powerful.

\section{Reduce the Frequency of Global Encounters}

Here is a final, offbeat suggestion designed to reduce the incidents of confrontational events. Virtually every meeting of global leaders generates a predictable response: protesters mass in an effort to close it down. This action should arouse our sense of irony because the protesters are right, albeit for the wrong reason. The yearly economic summit meetings of the heads of the major governments are not the occasion for the exercise of too much power, but too little. The phenomenon of highly-orchestrated annual meetings of world leaders has degenerated into costly global photo opportunities at which presidents and prime ministers strut on the world stage - and accomplish little of substance.

One of the easiest forecasts to make in advance of any annual summit is that, once again, the joint communiquй will be disappointingly bland. Thus, the protesters are fundamentally misguided in massing at summit cities in an effort to influence a supposedly powerful decision making operation. Few decisions of importance are made there. Today's summit meeting at its best is merely a colorful social occasion. The leaders of the major nations get to meet each other.

Each government represented feels obliged to send a huge delegation to back up its national leader. After all, who knows what technical questions will be raised? In any event, that justifies the presence of a vast array of supporting officials and staff members. Given the millions of dollars directly spent on these taxpayer-financed junkets - in addition to the substantial indirect costs for secu- 
rity, publicity, etc. - it is easy to conclude that the summit meetings flunk the simplest cost/benefit test. Under the circumstances, here is a modest proposal: declare a moratorium on global summits. At a minimum, cancel the meeting scheduled for the summer of 2002. Let the leaders instead use modern telecommunications to communicate. In plain language, they should pick up the phone to call. Use the money saved for some worthy endeavor such as providing emergency treatment for the sick.

It is safe to predict that, aside from folks who enjoy taking expensive international trips paid for by someone else, there will be little clamor to revive the expensive custom of holding frequent meetings of world leaders. Surely no serious government function will be adversely affected by not holding a global summit meeting later this year.

\section{Conclusion}

As the various sides in the debate on globalization continue to harden their positions, any movement to the high middle ground will become increasingly difficult. The development of a feeling of trust, or at least common understanding, is a badly needed precondition. ${ }^{10}$

Meanwhile, one modest change would help. The various participants in the often-heated discussions on globalization should consider moderating their vocabularies. So often the argument seems to be carried on between "greedy profiteering monopolists" and impractical free trade theorists," on one side, and "environmental whacks" and "corrupt union bosses" on the other. The introduction of a bit of mutual good will would surely help.

In any event, the serious concerns generated by a more closely linked global marketplace must be faced. A wider understanding is needed of both the dark side and the bright side of globalization. It is not feasible to take the position, "Stop the world, I want to get off."

${ }^{10}$ See Murray Weidenbaum, Looking for Common Ground on U.S. Trade Policy (Washington, D.C.: The Center for Strategic and International Studies, 2001) 